\title{
OJED
}

Volume 5, Issue 1 (2020), pp. 180-183

International Journal of

Multidisciplinary Perspectives in Higher Education

ISSN: 2474-2546 Print/ ISSN: 2474-2554 Online

https://ojed.org/jimphe

\section{The Intersection of Faculty Success and Student Success}

\author{
Elizabeth Smith \\ University of Tulsa, Oklahoma, USA
}

\begin{abstract}
With discreet limits on time to commit to their work, full-time faculty at research institutions are pulled in many directions in pursuit of tenure and promotion. In the existing rewards structure, student success may be deemphasized and considered a lower priority than research output. This essay re-frames the relationship between student success and faculty success, suggesting that the two can inform each other as faculty pursue tenure and promotion.
\end{abstract}

Keywords: faculty, student success, promotion and tenure

Retention, promotion, and tenure at research universities are built upon a rewards system that emphasizes faculty research productivity through publication (Bergeron, Ostroff, Schroeder, \& Block, 2014). With great variety related to institutional type, teaching and institutional and professional service are also valued, but often to a lesser extent (Price \& Cotten, 2006). While this essay focuses specifically on tenure-track faculty at research institutions, contract faculty and faculty at other types of institutions have greater expectations for teaching and service. Regardless of institution and position type, faculty have significant demands on their time in three areas: research, teaching, and service. At the same time, institutions are asking more of faculty in terms of supporting student engagement and student success. How can faculty with significant research expectations also support student success within the limits of their time? This essay explores the connection between student success and faculty 
success in circumstances when faculty success is tied significantly to research productivity.

Student success in terms of retention, graduation, and even postgraduation outcomes is a growing focus among institutions of higher education (Kuh, Ikenberry, Jankowski, Cain, Ewell, Hutchings, Kinzie, 2016). While institutions typically frame student success in terms of measurable outcomes, college students describe success differently, recognizing not just the end goal of graduation but also their college experience as key in their success. Jennings, Lovett, Cuba, Swingle, and Lindkvist (2013) found that college freshmen initially express their goals for college success around four themes: academic achievement, social and residential life, life management, and academic engagement. The authors followed college students for four years and saw that the importance of each area grew or waned over their time, but students consistently described academic achievement as their primary goal with social aspects of college life also meaningful to them.

If students largely define their success in terms of academic achievement and institutions define student success largely as persistence and graduation, how can faculty support student success while also pursuing their own success within the established rewards structure? How can supporting student success also support faculty success in research, teaching and service? Faculty content expertise deepened through research and knowledge-sharing skills honed through teaching and mentoring are discussed below as ways faculty can link their success with student success.

First, content expertise can be an important factor in student success. Content expertise is linked to research expertise; when faculty teach courses that are closely related to their research areas, students benefit from their deep knowledge of that content. Student motivation is an important factor in student learning and faculty with deep content expertise and passion for their research can build classrooms and learning experiences that engage students and help them see the value of what they are learning (Ambrose, Bridges, DiPetro, Lovett, \& Norman, 2010). Faculty with content expertise, supported by their research expertise, engage students in deeper learning which contributes to student academic achievement.

Students need instructors who are engaging content experts and have both content knowledge and pedagogical content knowledge (Shulman, 1987). Effective teaching through pedagogical content knowledge and content expertise work cooperatively to promote student learning and student academic success. Faculty teaching in their research areas also have the opportunity to work out new ideas, get feedback on ideas, and improve knowledge-sharing skills. Teaching can support a faculty member's research dissemination by preparing them for sharing their discoveries. The ability to clearly communicate research findings and share findings with an audience outside the content area are skills faculty develop through teaching 
that can support their success in research. Grant applications, writing research articles, and sharing findings at conferences require the ability to distill many years of knowledge and research into consumable quantities - a skill practiced when helping students understand difficult concepts.

In these ways, research and teaching are linked; deep content knowledge gained through research can positively impact student success while the ability to share complex information with simplicity can contribute to faculty success. Faculty and student success are further connected through service expectations for faculty. At research institutions, service is likely the least of the three priorities for faculty in pursuit of tenure, but it is required, nonetheless (Price \& Cotten, 2006). Faculty interested in student success can use their service time to mentor students, advise student groups, and support student growth outside the classroom. Student success supported through faculty service can also bolster faculty success in terms of research. Faculty can choose to include students in their research, giving students opportunities to learn research skills while also supporting faculty research. Faculty may also choose to mentor students who are applying for prestigious post-graduate fellowships. More broadly, faculty can serve the institution through creating new programs to recruit new students or better prepare students for life after college. Faculty who want to link student success and their own plans for tenure and promotion can take a strategic approach to service by using their expertise to mentor and lead students while also building a compelling case for tenure.

Faculty do not have to segment their work lives into three separate and distinct buckets of research, teaching, and service. Faculty success and student success are not in opposition to or independent of each other. Instead, faculty success and student success are intertwined such that faculty can pursue excellence in research, teaching, and service and apply their success in those areas to support student success.

\section{References}

Ambrose, S. A., Bridges, M. W., DiPetro, M., Lovett, M. C., \& Norman, M. K., (2010). How learning works: Seven research-based principles for smart teaching. Jossey-Bass.

Bergeron, D. M., Ostroff, C., Schroeder, T. D., \& Block, C. J. (2014). The dual effects of organizational citizen behavior: Relationships to research productivity and career outcomes in academe. Human Performance, 27(2), 99-128.

Goldrick-Rab, S., Richardson, J., \& Kinsley, P. (2018). \#RealCollege Guide to Assessing Campus Basic Needs Security. Wisconsin HOPE Lab. Retrieved from https://hope4college.com/wpcontent/uploads/2018/09/Basic-Needs-Insecurity-CollegeStudents.pdf 
Jennings, N., Lovett, S., Cuba, L., Swingle, J., \& Lindkvist, H. (2013). "What would make this a successful year for you? How students define success in college. Liberal Education, 99(2). Retrieved from https://www.aacu.org/publications-research/periodicals/whatwould-make-successful-year-you-how-students-define-success

Kuh, G. D., Ikenberry, S. O., Jankowski, N. A., Cain, T. R., Ewell, P. T., Hutchings, P., Kinzie, J. (2016). Using evidence of student learning to improve higher education. Jossey-Bass.

Price, J. \& Cotten, S. R. (2006). Teaching, research, and service: Expectations of assistant professors. The American Sociologist, 37(1), 5-21.

Shulman, L. S. (1987). Knowledge and teaching: Foundations of the new reform. Harvard Educational Review, 57, 1-22.

\footnotetext{
Author Bio

ELIZABETH E. SMITH, Ph.D., is Assistant Professor of Education at the University of Tulsa, Tulsa, Oklahoma, USA. Dr. Smith's research focuses on P-20 partnerships in education, the role of faculty in assessment, and P12 education policy.
} 